\title{
Pendampingan UMKM Dalam Meningkatkan Hasil Produksi Dan Hasil Penjualan Opak Makanan Khas Jawa Barat
}

\author{
Opan Arifudin ${ }^{1}$, Udin Wahrudin ${ }^{2}$, Fenny Damayanti Rusmana ${ }^{3}$, Rahman Tanjung ${ }^{4}$ \\ ${ }^{1}$ Program Studi Ekonomi Syariah, STEI Al-Amar Subang, Indonesia \\ ${ }^{2,3}$ Program Studi Perbankan Syariah, STEI Al-Amar Subang, Indonesia \\ ${ }^{4}$ Program Studi Pendidikan Guru Madrasah Ibtidaiyah, STIT Rakeyan Santang Karawang, \\ Indonesia
}

\begin{abstract}
ABSTRAK
Persaingan untuk mendapatkan pekerjaan sangat ketat sehingga membuka usaha menjadi alternatif dalam memilih mata pencaharian. Usaha Mikro Kecil dan Menengah (UMKM) merupakan sektor ekonomi nasional yang paling strategis dan menyangkut hajat hidup orang banyak sehingga menjadi tulang punggung perekonomian Nasional. Namun masalah yang dihadapi oleh usaha ataupun industri kecil kebanyakan adalah sumber modal, tenaga kerja, bahan baku pengelolaan industri dan pemasaran. Dengan pengabdian masyarakat terkait pendampingan UMKM pada jenis makanan tradisional Opak diharapkan dapat memberikan solusi UMKM. Metode penyelesaian masalah yang digunakan berdasar pada pendekatan manajemen dalam meningkatkan hasil produksi dan hasil penjualan dengan 4 (empat) tahapan pelaksanaan program yaitu persiapan, pelaksanaan, evaluasi dan pelaporan. Program yang dilakukan adalah pendekatan manajemen terkait jam kerja yang dibuat secara terstruktur dengan waktu 8 jam, memanfaatkan sosial media dan jasa antar sehingga pemesanan tidak hanya dilakukan secara konvensional saja dan komunikasi sangat baik antara pendamping dan mitra dalam mencapai tujuan pendampingan.
\end{abstract}

Kata Kunci: UMKM, Produksi, Penjualan

\section{PENDAHULUAN}

Saat ini persaingan untuk mendapatkan pekerjaan sangat ketat. Tingkat pendidikan dan kemampuan sangat dibutuhkan. Usaha Mikro Kecil dan Menengah (UMKM) adalah sektor ekonomi nasional yang paling strategis dan menyangkut hajat hidup orang banyak sehingga menjadi tulang punggung perekonomian Nasional. UMKM juga merupakan kelompok pelaku ekonomi terbesar dalam perekonomian di Indonesia dan telah terbukti menjadi kunci pengaman perekonomian Nasional dalam masa krisis ekonomi serta menjadi desiminator pertumbuhan ekonomi pasca krisis. Namun sebuah UMKM harus mampu mengikuti perkembangan zaman dalam rangka terus eksis. Menurut (Arifudin, 2020a) bahwa perkembangan dalam dunia usaha di Indonesia saat ini yang semakin cepat dan pesat berakibat juga pada perubahan budaya. Sehingga organisasi dituntut untuk mempunyai budaya yang membedakan dengan organisasi lain yang sejenis.

Didasarkan atas kondisi tersebut, pemerintah pada tahun 2009 mencanangkan tahun industri kreatif yang diyakini merupakan industri penggerak sektor rill ditengah ancaman melambatnya perekonomian akibat krisis global. Melalui Inpres No. 6 tahun 2009 mengenai pengembangan industri kreatif kepada 28 instansi pemerintah pusat dan daerah untuk mendukung kebijakan pengembangan industri kreatif tahun 2009-2015 yakni pengembangan kegiatan ekonomi berdasarkan pada kreatifitas, keterampilan, bakat individu yang bernilai ekonomi dan berpengaruh pada kesejahteraan masyarakat Indonesia. Peningkatan kesejahteraan hanya mungkin bila tanah dan modal mampu meningkatkan produksi lebih cepat dibanding angkatan tenaga kerja.

Usaha Mikro Kecil dan Menengah (UMKM) di Indonesia memiliki peran yang sangat penting terutama dalam hal penciptaan kesempatan kerja. Hal ini didasarkan pada kenyataan bahwa jumlah angkatan kerja di Indonesia sangat melimpah mengikuti jumlah penduduk yang besar sehingga Usaha Besar (UB) tidak sanggup menyerap semua pencari kerja dan 
ketidaksanggupan usaha besar dalam menciptakan kesempatan kerja yang besar disebabkan karena memang pada umumnya kelompok usaha tersebut relatif padat modal, sedangkan UMKM relatif padat karya. Sehingga tujuan pengabdian masyarkat terkait pendampingan UMKM Opak di Desa Cibuluh sangat vital bagi upaya memberikan kemajuan pada UMKM Opak yang dikelola di Desa Cibuluh Kecamatan Tanjungsiang Kabupaten Subang. Opak adalah makanan yang terbuat dari tepung beras, garam dapur, gula, dan macam-macam bumbu penyedap. Opak juga semacam kerupuk tapi opak ini sangat berbeda dari kerupuk pada umumnya rasa opak ini rasanya sangat gurih sering digunakan oleh masyarakat suku sunda sebagai cemilan.

Pada saat ini industri kecil sangat berkembang pesat dimasyarakat, seiring kemajuan teknologi dan permintaan pasar yang besar pada jenis-jenis barang tertentu. Perkembangan manusia yang pesat, memunculkan kebutuhan pangan yang meningkat. Terutama jenis panganan sehari-hari. Pengaruh usaha mikro kecil dan menengah (UMKM) ditengah-tengah masyarakat sangatlah besar, terutama dalam memberdayakan masyarakat yang tidak memiliki pekerjaan. Minimal individu dari masyarakat dapat memenuhi kebutuhan pribadinya dan jauh dari kemiskinan. Tidak berhenti disitu saja, peran UMKM mampu menghidupkan sektor lain seperti jasa distribusi dan angkutan transportasi, jasa sewa lahan produksi, industri manufaktur pembuat mesin produksi, industri kemasan, jasa periklanan (advertising), pemasaran, dan jasa design branding produk (jika diperlukan).

Industri kecil di pedesaan dikenal sebagai tambahan sumber pendapatan keluarga dan juga sebagai penunjang kegiatan pertanian yang merupakan mata pencaharian pokok sebagian besar masyarakat pedesaan. Industri pedesaan mempunyai arti penting dalam usaha mengurangi tingkat kemiskinan di pedesaan atau dengan kata lain orang yang bekerja atau karyawan diharapkan dapat meningkatkan kesejahteraannya. Menurut (Arifudin, 2019) bahwa karyawan adalah setiap orang yang bekerja dengan menjual tenaganya (Fisik dan Pikiran) kepada suatu perusahan dan memperoleh balas jasa sesuai dengan peraturan dan perjanjian.

Dalam upaya meningkatkan kesejahteraan masyarakat pedesaan tercermin pada sasaran pembangunan ekonomi skala besar kini telah menjadi perioritas pengembangan kedepan. Hal ini sesuai dengan intruksi presiden No. 6 Tahun 2009 tentang dukungan pengembangan ekonomi kreatif. Dukungan ini diharapkan untuk mengembangkan ekonomi yang ada dipedesaan sehingga dapat berpengaruh secara nyata bagi perekonomian ekonomi. Opak merupakan karya teknologi pangan Indonesia, khususnya yang sangat disukai oleh mayoritas penduduk Indonesia. Opak adalah makanan kegemaran yang tidak hanya dikonsumsi oleh masyarakat kelas bawah dan menengah saja, melainkan makanan yang dikonsumsi kelas atas baik perdesaan maupun perkotaan. Industri kecil Opak di desa Cibuluh adalah salah satu industri kecil yang ada di Kecamatan Tanjungsiang Kabupaten Subang. 


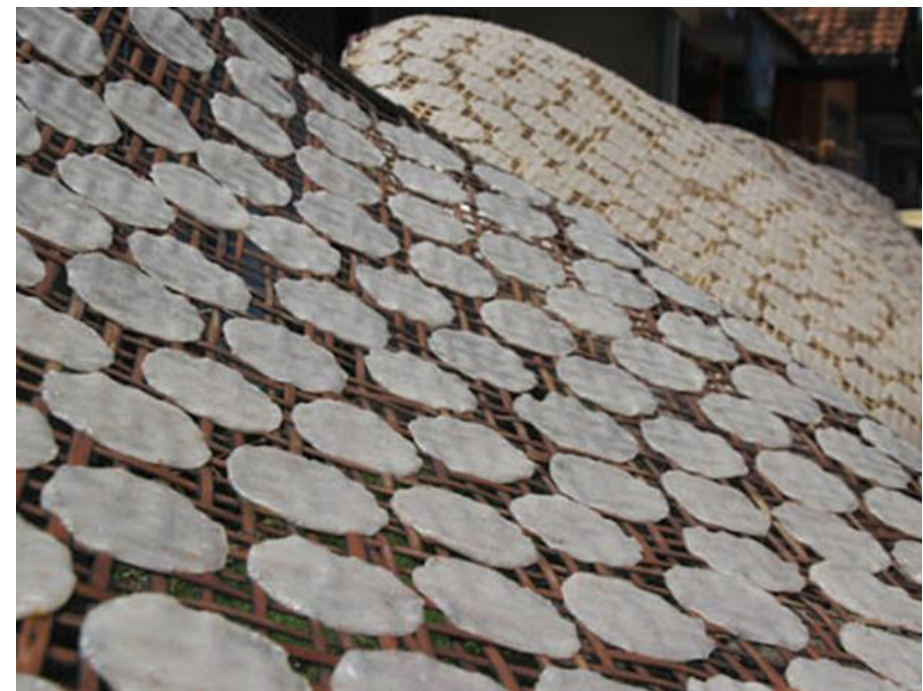

Gambar 1. Proses pemanggangan Opak secara alami dengan sinar matahari

Masalah yang sering dihadapi oleh usaha ataupun industri kecil kebanyakan adalah sumber modal, tenaga kerja, bahan baku dan pemasaran. Modal sebagai dana yang digunakan untuk menjalankan kegiatan produksi sangatlah penting dalam strategi untuk mengembangkan sebuah usaha. Kekuatan yang dimiliki usaha dapat berasal dari modal yang dimiliki. Marketing atau pemasaran merupakan kegiatan penting dari perusahaan yang menghasilkan produk untuk dijual, dengan tujuan memperoleh keuntungan. Dengan keuntungan tersebut diharapkan perusahaan bersangkutan bukan saja dapat mempertahankan kelanjutan usahanya, tetapi juga dapat dikembangkan lebih besar.

Dalam rangka meningkatkan hasil penjualan ini, dibutuhkan metode pemasaran yang tepat. Inti dari pemasaran (Marketing) menurut (Kotler, Philip, 2012) adalah mengidentifikasi dan memenuhi kebutuhan manusia dan sosial. Sehingga lebh lanjut bahwa pemasaran adalah suatu fungsi organisasi dan serangkaian proses untuk menciptakan, mengkomunikasikan, dan memberikan nilai kepada pelanggan dan untuk mengelola hubungan pelanggan dengan cara yang mengguntungkan organisasi dan pemangku kepentingannya. Pendapat lain menurut (Tambajong, 2013) bahwa pemasaran adalah suatu sistem dari kegiatan bisnis yang dirancang untuk merencanakan, menentukan harga, mempromosikan dan mendistribusikan produk yang dapat memuaskan keinginan dalam mencapai tujuan perusahaan.

Dalam upaya memperluas pemasaran ini, dibutuhkan inovasi dalam produksi. Menurut Shepherd dalam (Damayanti, 2020) bahwa inovasi tidak hanya terbatas pada benda atau barang hasil produksi, tetapi juga mencakup sikap hidup, perilaku, atau gerakangerakan menuju proses perubahan di dalam segala bentuk tata kehidupan masyarakat. Inovasi ini akan berdampak pada kemajuan UMKM Opak. Menurut (Arifudin, 2020) bahwa dalam sebuah usaha Inovasi, peningkatan produksi dan pemasaran merupakan hal yang sangat penting dalam kemajuan sebuah perusahaan. Hal ini sejalan dengan pendapat (Sari, 2015) bahwa inovasi selalu menjadi kunci keberhasilan dan kesuksesan suatu usaha. Sehingga dalam rangka meningkatkan produksi dan hasil penjualan dibutuhkan inovasi yang dilakukan UMKM.

\section{Manfaat Pengabdian Pada Masyarakat}

Dari kegiatan pengabdian pada masyarakat ini diharapkan masyarakat khususnya yang terlibat dalam UMKM Opak memperoleh kesejahteraan dengan mengoptimalkan 
pengelolaan produksi dengan pendekatan manajemen dan konsep pemasaran terkait hasil penjualan UMKM Opak Desa Cibuluh Kecamatan Tanjungsiang Kabupaten Subang. Selain itu kegiatan pengabdian pada masyarakat ini diharapkan dapat melestarikan makanan tradisional khas Jawa Barat, ditengah bermunculannya makanan-makanan dari luar negeri.

\section{Solusi Dan Target Kegiatan}

Kegiatan pengabdian pada masyarakat berupa "Pendampingan UMKM Dalam Meningkatkan Hasil Produksi Dan Hasil Penjualan Opak Makanan Khas Jawa Barat", sebagai upaya membantu kesejahteraan masyarakat Desa Cibuluh Kecamatan Tanjungsiang Kabupaten Subang. Oleh karena itu target dan sasaran pendampingan ini adalah kepada : UMKM dan masyarakat yang bergerak dalam UMKM Opak ini. Dengan adanya Pendampingan UMKM Dalam Meningkatkan Hasil Produksi Dan Hasil Penjualan Opak Makanan Khas Jawa Barat, dapat memberikan kemanfaatan dan solusi yakni sebagai berikut

1. Membantu pengurusan ijin usaha dan P-IRT sehingga Opak dapat dijual lebih luas lagi.

2. Memperbaiki kemasan produk opak dengan membuat kemasan didesain sesuai dengan standar yang telah di tetapkan Dinas Kesehatan dan agar lebih menarik.

3. Menerapkan manajemen pada proses produksi UMKM opak.

Target luaran Pendampingan UMKM Dalam Meningkatkan Hasil Produksi Dan Hasil Penjualan Opak Makanan Khas Jawa Barat adalah sebagai berikut :

1. Menumbuhkan inovasi dalam menjalankan usaha.

2. Meningkatkan etos kerja dengan pendekatan manajemen agar hasil produksi meningkat.

3. Meningkatkan pengetahuan mengenai pemasaran konvensional maupun online agar hasil penjualan meningkat.

4. Meningkatkan pendapatan UMKM Opak.

\section{METODE PELAKSANAAN}

Metode dalam pelaksanaan program pengabdian masyarakat interdisipliner yang dilakukan oleh Dosen pada 2 (dua) perguruan tinggi dilingkungan kementerian agama yakni STEI AlAmar Subang dan STIT Rakeyan Santang Karawang. Dalam mendampingi UMKM Opak Desa Cibuluh Kecamatan Tanjungsiang Kabupaten Subang Jawa Barat dilakukan dengan beberapa tahapan pelaksanaan program, yaitu sebagai berikut :

\section{Tahapan awal}

1. Tahapan ini dilakukan oleh Dosen dengan menyiapkan data-data yang dibutuhkan terkait UMKM Opak di Desa Cibuluh Kecamatan Tanjungsiang Kabupaten Subang Jawa Barat. Hal ini dibutuhkan untuk memastikan pendampingan seperti apa yang tepat dengan juga melihat kultur di Desa yang bersangkutan sebagai pertimbangan.

2. Menyiapkan program-program pengabdian masyarakat untuk di sosialisasikan kepada UMKM Opak Desa Cibuluh Kecamatan Tanjungsiang Kabupaten Subang Jawa Barat dengan design utama adalah peningkatan produksi dan hasil penjualan Opak.

3. Menyiapkan peralatan, sarana-prasarana pendukung untuk pelaksanaan program dan formula strategi pelaksanaan program secara tahap demi tahap berdasarkan prioritas program pendampingan UMKM Opak Desa Cibuluh Kecamatan Tanjungsiang Kabupaten Subang Jawa Barat. 


\section{Tahapan pelaksanaan}

1. Mengemukakan strategi proses pelaksanaan program pendampingan UMKM Opak untuk menerapkan pola manajemen terhadap mitra sehingga diharapkan memberikan dampak dan perubahan terhadap mitra sasaran program sesuai dengan tujuan pengabdian masyarakat pendampingan UMKM Opak.

2. Tahapan pelaksanaan ini merupakan adanya komunikasi sinergi dengan mitra terkait keaktifan, peran dan kontribusi mitra sasaran pelaksanaan program pengabdian masyarakat pendampingan UMKM Opak.

3. Dalam proses pengabdian masyarakat pendampingan UMKM Opak akan dilakukan terus koordinasi terkait progress dari pengabdian masyarakat pendampingan UMKM Opak ini baik berupa data kuantitatif yang diukur selama pelaksanaan program.

4. Data kuantitatif ini merupakan referensi yang terus dipantau oleh Dosen STEI AlAmar Subang yang dihasilkan pada mitra sasaran sebagai data hasil kegiatan, baik data secara kuantitatif (misalnya jumlah produksi, jumlah omzet, jumlah kader masyarakat, luasan lahan, jumlah tanaman dll) maupun data kualitatif (misalnya kualitas produk, jenis produk, diversifikasi produk, perubahan perilaku masyarakat, keberadaan manajemen usaha/manajemen sosial dan sebagainya).

\section{Tahapan monitoring dan evaluasi}

1. Proses monitoring dan evaluasi terhadap pelaksanaan program dilakukan setiap minggu dalam 3 (tiga) bulan masa pengabdian masyarakat pendampingan UMKM Opak.

2. Metode evaluasinya yang digunakan menggunakan metode deskriptif yaitu penelitian lapangan (Field Research) dengan penyelidikan mendalam yang dilakukan dengan suatu prosedur penelitian lapangan. Penelitian ini juga menggunakan data deskriptif kualitatif, yaitu penelitian yang ditujukan untuk mendiskripsikan atau menggambarkan fenomena-fenomena yang ada, baik fenomena yang bersifat alamiah ataupun rekayasa manusia.

\section{HASIL DAN PEMBAHASAN}

Berdasarkan hasil dari pengabdian masyarakat Dosen STEI Al-Amar Subang dan STIT Rakeyan Santang Karawang dengan program pendampingan UMKM Opak Desa Cibuluh Kecamatan Tanjungsiang Kabupaten Subang Jawa Barat dapat dijelaskan hasil dan luaran program serta dampaknya terhadap perubahan mitra selama proses pendampingan mengalami peningkatan secara signifikan baik dari hasil produksi maupun penjualan dari produksi.

Hal ini dapat dilihat dari berbagai tahapan pengabdian masyarakat yang dilakukan yakni sebagai berikut :

\section{Tahapan Awal}

Pada tahap ini dilaksanakan observasi ke lokasi mitra dan wawancara dengan pemilik usaha UMKM Opak. Dari hasil observasi dan wawancara dengan mitra ditemukan permasalahan yang dialami oleh mitra sebagai berikut:

1. Usaha mitra belum memiliki P-IRT

2. Mitra mengalami kendala dalam melakukan proses pengurusan P-IRT karena kondisi tempat produksi usaha yang tidak memenuhi syarat.

3. Mitra tidak memiliki kemasan yang memadai untuk dijual lebih luas. 
Permasalahan-permasalahan di atas perlu diatasi agar usaha mitra dapat lebih berkembang lagi. Berdasarkan permasalahan yang ditemui di atas maka solusi yang ditawarkan pengabdian kepada masyarakat pada UMKM Opak Desa Cibuluh Kecamatan Tanjungsiang Kabupaten Subang Jawa Barat sebagai mitra dalam kegiatan pengabdian ini terbagi pada aspek produksi dan pemasaran produk, yaitu :

1. Aspek Produksi

Solusi dari aspek produksi yang ditawarkan oleh dosen pendamping dalam pengabdian ini adalah sebagai berikut :

1) Membantu pengurusan ijin usaha dan P-IRT sehingga Opak dapat dijual lebih luas lagi.

2) Memperbaiki kemasan produk Opak dengan membuat kemasan didesain sesuai dengan standar yang telah di tetapkan Dinas Kesehatan dan agar lebih menarik.

3) Menerapkan manajemen pada proses produksi UMKM Opak.

4) Aspek Pemasaran dapat diperluas dengan pemanfaatan sosial media dan platform online dalam pemasaran produk. Solusi dari permasalahan pemasaran yang ditawarkan dalam Program Kemitraan Masyarakat ini adalah memperluas pemasaran ke pasar modern dan pemasaran secara online.

\section{Tahapan Pelaksanaan}

Dalam produksi mitra mengalami masalah karena proses produksi dilakukan tanpa pendekatan manajemen serta belum memahami dalam mengurus Sertifikat Industri Rumah Tangga Pangan (P-IRT) dan izin usaha. Hal ini terlihat dari jam kerja yang tidak jelas, perencanaan produksi yang belum ada dan capaian produksi yang tidak jelas setiap waktunya. Hal ini terjadi karena semua pekerjanya juga merupak ibu rumah tangga yang mengurus keluarganya.

Tim pengabdian masyarakat mendampingi mitra dalam mengelola UMKM dengan pendekatan manajemen, membantu untuk mengurus Sertifikat Industri Rumah Tangga Pangan (P-IRT), dan memperluas pemasaran menggunakan platform online serta ke tokotoko yang lebih besar.

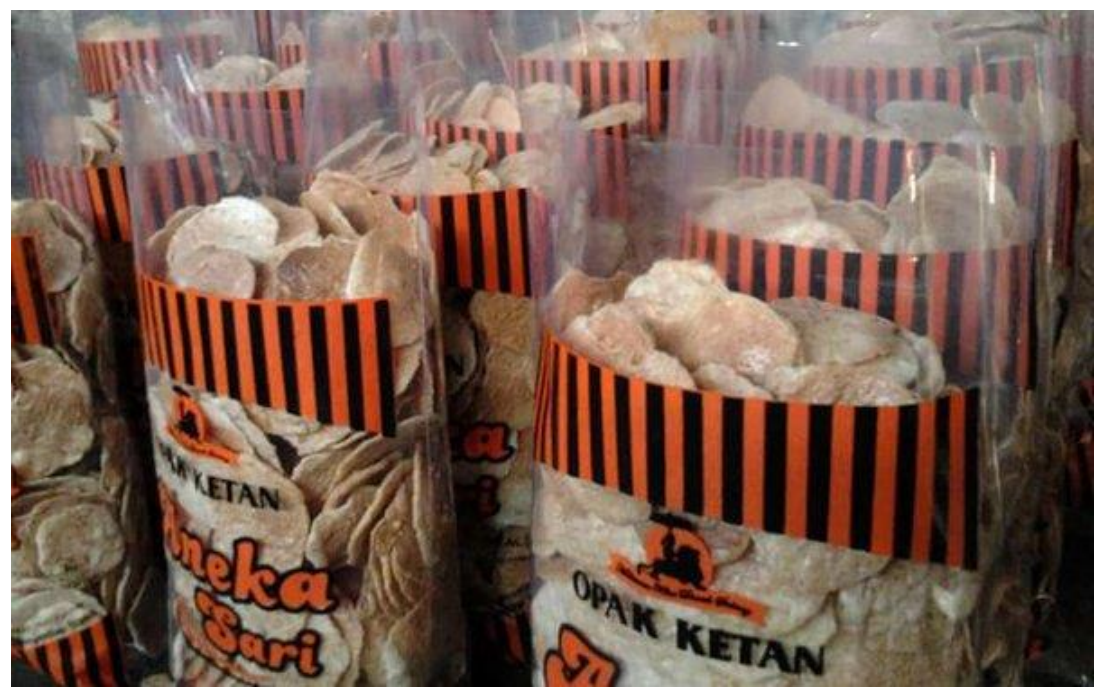

Gambar 2. Kemasan Opak dengan (P-IRT)

Dampak dari program pengabdian masyarakat Dosen STEI Al-Amar Subang dan STIT Rakeyan Santang Karawang dengan program pendampingan UMKM Opak Desa Cibuluh Kecamatan Tanjungsiang Kabupaten Subang Jawa Barat terhadap mitra sangat 
besar terkait peningkatan hasil produksi maupun penjualan dari produksi berdasar data setiap bulan dengan rentang waktu pendampingan selama 3 (tiga) bulan dari bulan februari, maret dan april tahun 2019. Perlu diketahui bahwa dalam penyelenggaraan produksi ini hanya melibatkan 2 (dua) orang pekerja pada UMKM opak Desa Cibuluh Kecamatan Tanjungsiang Kabupaten Subang Jawa Barat. Program yang dilakukan adalah pendekatan manajemen terkait jam kerja yang dibuat secara terstruktur dengan waktu 8 jam. Hal ini merupakan perubahan dari jam kerja yang tidak tentu dalam penyelenggaraan produksi UMKM tersebut.

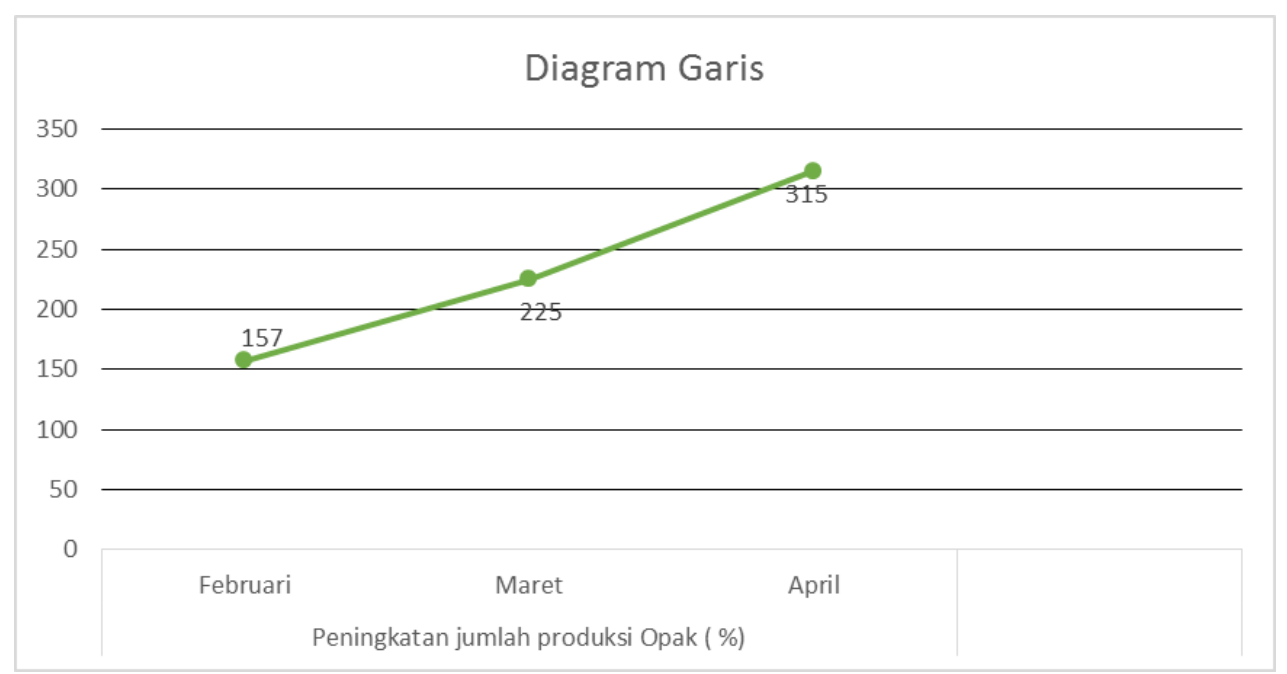

Diagram 1.Peningkatan Jumlah produksi Opak 2019

Program pendampingan UMKM Opak Desa Cibuluh Kecamatan Tanjungsiang Kabupaten Subang Jawa Barat adalah meningkatkan jumlah produksi dan hasil penjualan. Hal ini sesuai dengan design awal program pendampingan terhadap mitra, berdasarkan datadata yang diperoleh tahun 2018 pada 3 (tiga) bulan yakni februari, maret dan april sebelum pendampingan pada dilakukan adalah sebagai berikut :

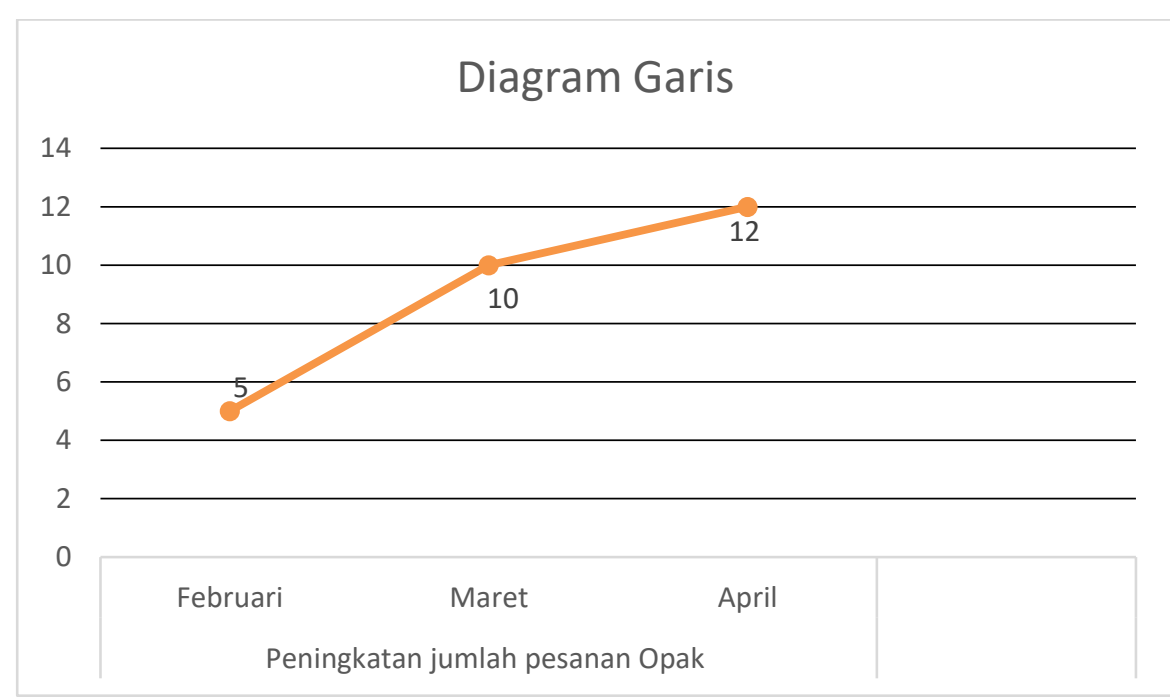

Diagram 2. Data Produksi Sebelum Pendampingan 2018

Dengan pendekatan manajemen yang dilakukan oleh Dosen STEI Al-Amar Subang dan STIT Rakeyan Santang Karawang pada pendampingan UMKM Opak Desa Cibuluh Kecamatan Tanjungsiang Kabupaten Subang Jawa Barat, ini sangat efektif terhadap 
pencapaian tujuan program pendampingan dalam meningkatkan hasil produksi dan penjualan opak. Metode pemanfaatan manajemen memiliki peran vital dalam pencapaian tujuan program pendampingan terhadap mitra, UMKM tersebut pada awalnya dikelola secara sederhana tanpa pola.

Adapun terkait penjualan Opak yang biasanya hanya berdasarkan pesanan masyarakat yang membutuhkan. Pendekatan marketing dilakukan oleh Dosen STEI AlAmar Subang dan STIT Rakeyan Santang Karawang dengan memanfaatkan sosial media dan jasa antar, sehingga pemesanan tidak hanya dilakukan secara konvensional saja. Berdasarkan data yang diperoleh pada rentang waktu pendampingan selama 3 (tiga) bulan dari bulan februari, maret dan april tahun 2019 mengalami peningkatan yang signifikan.

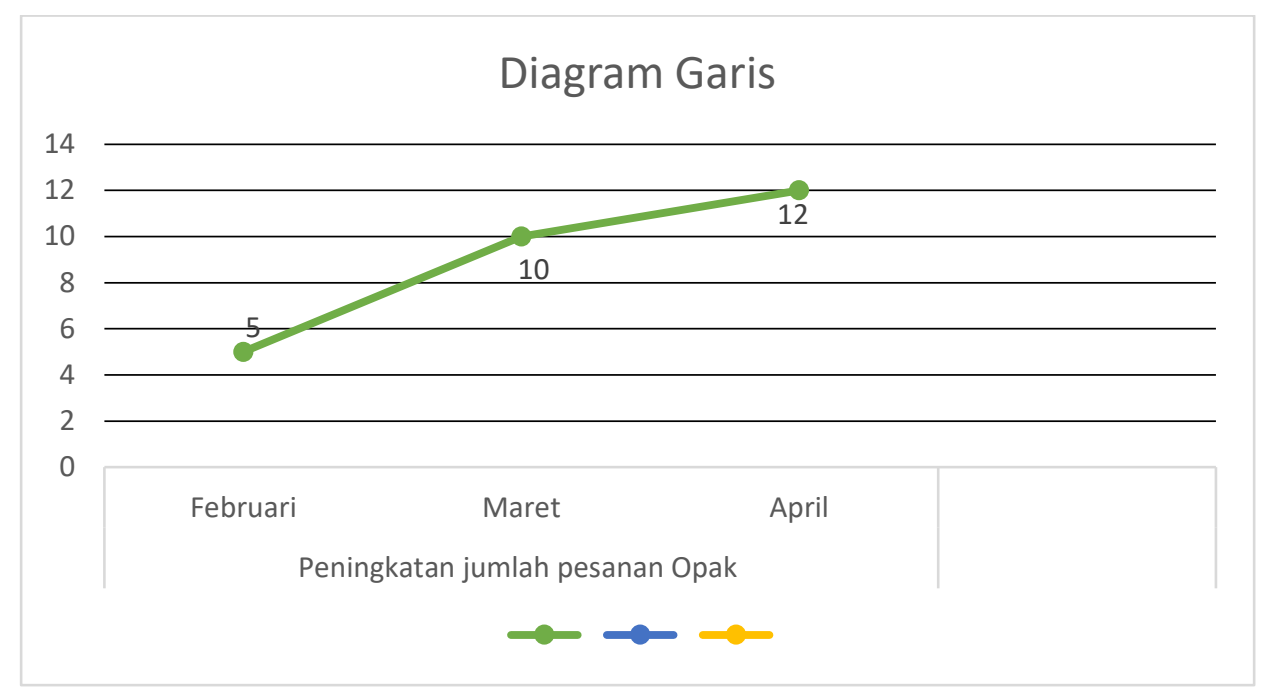

Diagram 3. Data Pesanan Setelah Pendampingan 2019

\section{Tahapan Monitoring dan Evaluasi}

Dalam melaksanakan program pendampingan UMKM Opak Desa Cibuluh Kecamatan Tanjungsiang Kabupaten Subang Jawa Barat, ada berbagai kendala yang dihadapi oleh Dosen STEI Al-Amar Subang dan STIT Rakeyan Santang Karawang dalam memberikan pendampingan mitra. Kendala dilapangan adalah merubah kultur pengelolaan UMKM, karena pada awalnya UMKM dikelola tanpa adanya pendekatan manajemen dengan menggunakan pola sederhana tanpa ada aturan waktu maupun target produksi. Kendala ini sangat berpengaruh terhadap ketercapain program sehingga pada bulan ke-1 pendampingan dalam meningkatkan hasil produksi dan penjualan tidak cukup signifikan dengan data hasil sebelum program pendampingan. Solusi yang diambil oleh Dosen STEI Al-Amar Subang dan STIT Rakeyan Santang Karawang dalam merubah kultur adalah dengan orientasi hasil sehingga para pekerja dan pemilik UMKM mendapat stimulus dalam mengimplementasikan pendekatan manajemen pada UMKM Opak Desa Cibuluh Kecamatan Tanjungsiang Kabupaten Subang Jawa Barat.

Dalam penyelenggaraan program pendampingan UMKM Opak Desa Cibuluh Kecamatan Tanjungsiang Kabupaten Subang Jawa Barat penggunaan metode pendampingan, monitoring dan evaluasi pelaksanaan program untuk mencapai tujuan program sangat efektif. Hal ini sebagai dampak dari proses komunikasi sangat baik antara pendamping dan mitra. Mitra sangat terbantu akan kehadiran pendampingan baik pada tataran teoritis maupun praktis. Hal ini pun mendapat dukungan dari pemerintah setempat terkait salah satu program Desa setempat dalam pembangunan Desa wisata terpadu. 
Penyelenggaraan program pendampingan UMKM Opak Desa Cibuluh Kecamatan Tanjungsiang Kabupaten Subang Jawa Barat, terkait perubahan yang dialami oleh mitra program selama dan setelah pelaksanaan program dilakukan dapat dilihat dari 3 indikator perubahan yang dapat disimpulkan berdasar pada data-data yang diperoleh dalam setiap monitoring dan evaluasi program terhadap mitra. Indikator ini terdiri dari pengelolaan, produktifitas dan Hasil Penjualan.

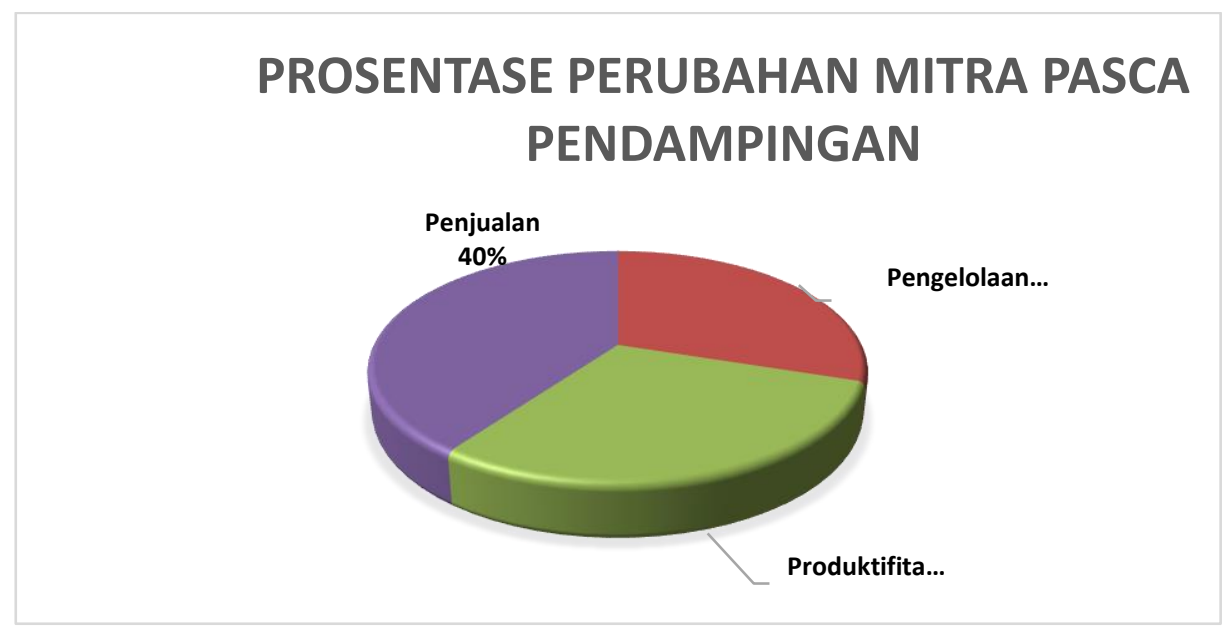

Diagram 4. Data evaluasi perubahan mitra 2019

Data-data empiris yang di dapat selama proses pendampingan UMKM Opak Desa Cibuluh Kecamatan Tanjungsiang Kabupaten Subang Jawa Barat sejalan dengan teori Jhon Stuart Mill dalam (Bernadetha, 2020) yang mengemukakan bawha pembangunan ekonomi sebagai fungsi dari tanah, tenaga kerja, dan modal. Sementara tanah dan tenaga kerja adalah dua faktor produksi yang asli, dan modal adalah persediaan yang dikumpulkan dari produkproduk tenaga kerja sebelumnya. Peningkatan kesejahteraan hanya mungkin bila tanah dan modal mampu meningkatkan produksi lebih cepat dibanding angkatan tenaga kerja. Tujuan pendampingan UMKM Opak Desa Cibuluh Kecamatan Tanjungsiang Kabupaten Subang Jawa Barat adalah pada penigkatan hasil produksi agar meningkatkan kesejahteraan masyarakat Desa pada UMKM Opak hanya dapat dicapai apabila produksi dapat ditingkatkan.

\section{KESIMPULAN DAN SARAN}

\section{Kesimpulan}

Berdasar pada kesimpulan dari program pengabdian masyarakat Dosen STEI Al-Amar Subang dengan program pendampingan UMKM Opak Desa Cibuluh Kecamatan Tanjungsiang Kabupaten Subang Jawa Barat terhadap mitra dalam meningkatkan jumlah produksi dan hasil penjualan, hal ini sesuai dengan design awal program pendampingan terhadap mitra berdasarkan data-data yang ada diperoleh 3 (tiga) bulan sebelum pendampingan. Program pendampingan UMKM Opak Desa Cibuluh Kecamatan Tanjungsiang Kabupaten Subang Jawa Barat, terkait perubahan yang dialami oleh mitra program selama dan setelah pelaksanaan program dilakukan dapat dilihat dari 3 indikator perubahan yang dapat disimpulkan berdasar pada data-data yang diperoleh dalam setiap monitoring dan evaluasi program terhadap mitra. Indikator ini terdiri dari pengelolaan, produktifitas dan Hasil Penjualan. 


\section{Saran}

Adapun saran yang bisa diberikan atas pelaksanaan Program pengabdian kepada masyarakat kepada UMKM Opak Desa Cibuluh Kecamatan Tanjungsiang Kabupaten Subang Jawa Barat, adalah sebagai berikut :

1. Untuk terus konsisten dalam menjalankan UMKM Opak makanan tradisional dibutuhkan pendekatan manajemen yg konsekuen sehingga perbaikan bukan saat pendampingan saja tetapi juga menjadi budaya baru UMKM.

2. Dibutuhkan semangat terus belajar guna terus berinovasi dalam pengembanag usaha ke depan agar bisa bersaing dengan usaha yang lain.

3. Adanya kesamaan tujuan antara pemilik dan karyawan agar UMKM Opak makanan tradisional ini bisa mensejahteraan kehidupan semuanya.

\section{DAFTAR PUSTAKA}

Arifudin, O. (2019). Pengaruh Kompensasi Terhadap Kinerja Karyawan Di PT. Global (PT.GM). Jurnal Ilmiah MEA (Manajemen, Ekonomi, \& Akuntansi), 184-190. Volume 3, No 2, Mei 2019

Arifudin, O. (2020). Analisis Budaya Organisasi Dan Komitmen Organisasi Karyawan Bank Swasta Nasional Di Kota Bandung. Jurnal Ilmiah MEA (Manajemen, Ekonomi, Dan Akuntansi), Manajemen, Ekonomi, dan Akuntansi), 73-87. Volume 4, No 2, Mei 2020

Arifudin, O. (2020). PKM Pembuatan Kemasan, Peningkatan Produksi Dan Perluasan Pemasaran Keripik Singkongdi Subang Jawa Barat. INTEGRITAS: Jurnal Pengabdian, Vol 4(No 1), 21-36.

Bernadetha. (2020). Manajemen Humas Pada Lembaga Pendidikan. Bandung: Widina Bhakti Persada.

Damayanti, F. (2020). Prilaku konsumen dan perkembangannya di era digital. Bandung: Widina Bhakti Persada.

Kotler, Philip, dan G. A. (2012). Prinsip-prinsip Pemasaran. Edisi 13. Jakarta : Erlangga.

Sari, S. W. dan R. M. (2015). Pendampingan Pengembangan Geblek Pedas Pada Wirausaha Pembuatan Geblek Di Dusun Dusun Balong V, Desa Banjarsari, Kecamatan Samigaluh, Kulon Progo, Yogyakarta. Jurnal Inovasi Dan Kewirausahaan, 4(3), 206210.

Tambajong, G. (2013). Bauran Pemasaran Pengaruhnya Terhadap Penjualan Sepeda Motor Yamaha Di Pt. Sarana Niaga Megah Kerta Manado. Jurnal EMBA, 1(1), 1291-1301. 